\section{らなる開発が期待される.}

また，バリアメタルの一例として紹介した選択 CVD

一Wによるコンタタト埋め込み法は、コンタクトサイズ のさらなる微細化に対する有効な技術である.コンタク トのみならずスルーホール埋め込み等への応用範囲の拡 張が望まれる。

\section{文 献}

1) T. Nozaki and H. Okabayashi, J. Electrochem. Soc. Vol. 128, No. 1, p. 175, 1981.
2) H. Ishikawa, et. al., IEEE Trans. on Electron Devices.

3) T. Amazawa and H. Oikawa, Extended Abstract of the 15 ih Conference of SSDM 1983, pp 229-232.

4) O. Kudoh, et. al., J. Appl. Phys., 52 (1)p.486 1981.

5) N. Yamamoto, et. al., J. Electrochem. Soc. SST, Vol. 133, No. 2, p. 401, 1986.

6) N. Yamamoto, et. al, Proc. Second Int. Syn p. VLSI Science and Technology 1984 (Electrochem.) p. 361.

7) T. Amazawa, et. al., Extended Abstract of the 16 th Conf. on SSDM, pp 269-272 1984.

\title{
4t 金属ケイ化物
}

石川 元

1 はじめに

LSI の第 1 層，第 2 層配線は LSI を践成するトラン ジスタの電極に使われる多結晶シリコン(ポリシリコン) で形成する場合が多い. LSI の高集積化にともない，ポ リシリコン層の抵抗值がデバイスの高速動作の障害に なってきている.このため, 低抵抗率の電極, 配線材料 である高融点金属, あるいは, そ机のケイ化物（シリサ イド)でポリシリコンを置き換える動きがある. 特にあ る種のシリサイドは, 物理・化学的性質がポリシリコン によく似ており，LSI 製作プロセスを大幅に変更するこ となく，使用できる利点があり，LSI への利用が本格化 している，例えば，い上い上量産が始まろうとしている
4 メガビット DRAM では, 大半のメーカーが, シリ サイドまたは，ポリサイド(シリサイドとポリシリコン の 2 層構造）を採用している.

\section{1 シリサンドの種穎}

周期律表上の半分以上の物質はシリコンと反応してケ イ化物すなわちシリサイドを形成する．このうち LSI の配線材料として興味のあるシリサイドは, 高融点金属 のシリサイド，なかです，モリブデン，タングステン， チタンのシリサイドである，表 1 にLSI 配線で良く使 用されるシリサイドの組成を示す。シリサイドの組成は

表 1 LSI の配線に使用されるシリサイド

\begin{tabular}{|c|c|c|c|c|c|}
\hline $\mathrm{IV}-\mathrm{A}$ 族 & $\mathrm{V}-\mathrm{A}$ 族 & $\mathrm{VI}-\mathrm{A}$ 族 & \multicolumn{3}{|c|}{ VIII 族 } \\
\hline $\begin{array}{l}\mathrm{Ti}_{3} \mathrm{Si}_{3} \\
\mathrm{TiSi} \\
\mathrm{TiSi}_{2}\end{array}$ & $\begin{array}{l}\mathrm{V}_{3} \mathrm{Si} \\
\mathrm{V}_{5} \mathrm{Si}_{3} \\
\mathrm{VSi}_{2}\end{array}$ & $\begin{array}{l}\mathrm{Cr}_{3} \mathrm{Si} \\
\mathrm{CrSi} \\
\mathrm{CrSi}_{2}\end{array}$ & $\begin{array}{l}\mathrm{Fe}_{3} \mathrm{Si} \\
\mathrm{FeSi} \\
\mathrm{FeSi}_{2}\end{array}$ & $\begin{array}{l}\mathrm{Co}_{2} \mathrm{Si} \\
\mathrm{CoSi} \\
\mathrm{CoSi}_{2} \\
\mathrm{CoSi}_{3}\end{array}$ & $\begin{array}{l}\mathrm{Ni}_{2} \mathrm{Si} \\
\mathrm{NiSi} \\
\mathrm{NiSi}_{2}\end{array}$ \\
\hline $\begin{array}{l}\mathrm{Zr}_{2} \mathrm{Si} \\
\mathrm{ZrSi} \\
\mathrm{ZrSi}_{2}\end{array}$ & $\begin{array}{l}\mathrm{Nb}_{3} \mathrm{Si} \\
\mathrm{Nb}_{5} \mathrm{Si}_{3} \\
\mathrm{NbSi}_{2}\end{array}$ & $\begin{array}{l}\mathrm{Mo}_{3} \mathrm{Si} \\
\mathrm{Mo}_{5} \mathrm{Si}_{3} \\
\mathrm{MoSi}_{2}\end{array}$ & $\begin{array}{l}\mathrm{RuSi} \\
\mathrm{Ru}_{2} \mathrm{Si}_{3}\end{array}$ & $\begin{array}{l}\mathrm{Rh}_{2} \mathrm{Si} \\
\mathrm{RhSi}\end{array}$ & $\begin{array}{l}\mathrm{Pd}_{2} \mathrm{Si} \\
\mathrm{PdSi}\end{array}$ \\
\hline $\begin{array}{l}\mathrm{Hf}_{2} \mathrm{Si} \\
\mathrm{HfSi} \\
\mathrm{HfSi}_{2}\end{array}$ & $\begin{array}{l}\mathrm{Ta}_{2} \mathrm{Si} \\
\mathrm{Ta}_{5} \mathrm{Si}_{3} \\
\mathrm{TaSi}_{2}\end{array}$ & $\begin{array}{l}\mathrm{W}_{5} \mathrm{Si}_{3} \\
\mathrm{WSi}_{2}\end{array}$ & $\begin{array}{l}\text { OsSi } \\
\mathrm{OsSi}_{2} \\
\mathrm{OsSi}_{3}\end{array}$ & $\begin{array}{l}\mathrm{Ir}_{2} \mathrm{Si} \\
\mathrm{IrSi} \\
\mathrm{IrSi}_{2} \\
\mathrm{IrSi}_{3}\end{array}$ & $\begin{array}{l}\mathrm{Pt}_{2} \mathrm{Si} \\
\mathrm{PtSi}\end{array}$ \\
\hline
\end{tabular}

株式会社富士通研究所（部 243-01 厚木市森の里若宮 10-1) 
表に示すように $\mathrm{M}_{\mathrm{m}} \mathrm{Si}_{\mathrm{n}}$ ( $\mathrm{M}$ は金属)で表される. $(\mathrm{m}, \mathrm{n})$ の組み合わせは， $(2,1),(1,1),(1,2)$ が一般に多い，一 般に,シリコンと金属との反応開始温度は融点よりはる かに低い，低温固相反応でシリサイドが形成されるため 亡考えられている. LSI 製作プロセスで使用される熱処 理を通した場合, シリサイドの組成は変化し，一般に, シリコンリッチのシリサイド，特に高融点シリサイドで はジシリサイド $\left(\mathrm{MSi}_{2}\right)$ になる傾向がある.

\section{2 シリサイドの物性}

シリサイド単結晶の抵抗率は, 例えば $\mathrm{TiSi}_{2}, \mathrm{TaSi}_{2}$, $\mathrm{WSi}_{2}$ では室温でそれぞれ，11, 26,7 $\mu \Omega-\mathrm{cm}$ 上報告 されている.この值は, 金属に比べると約 1 桁高いが, ポリシリコンで実現している抵抗率に比べると約 2 枌低 い，LSI に使用するシリサイド薄膜は，多結晶構造なの で，抵抗率は単結晶より高い值になり，膜の形成条件や 形成後の熱処理条件により大幅にかわる. 通常の方法で 形成したシリサイド膜の抵抗は非常に高く，熱処理を加 えるこよにより，抵抗值はさがって単結晶の值に近づく， 熟処理によってシリサイド粒子の粒径が大きくなること などによる.

．LSI の配線材料では, フッ酸(シリコン酸化膜エッ チング液)に対して耐性があり，かつ，それ自身はエッ チング加工が簡単にできることが要求される.フッ酸に 耐性があるのは，モリブデンおょ恀ングステンのシリ サイドだけで, 主としてこの二つが LSI 配線に導入さ れている.

\section{3 シリサイド膜の形成方法}

シリサイド膜の代表的な形成方法は次の 3 種類であ ろ.

（1）金属膜と下地シリコンとの合金反応

(2) スパッ夕蒸着

(3) CVD

（1）は，真空蒸着，スパッ夕蒸着，CVD 法で金属膜 を形成し, 高温熱処理により下地シリコンと合金化反応 を起こして，シリサイドを形成する．下地にシリコンが ある領域が，シリサイド反応を起こすので，LSI では， 選択的にシリサイドを形成したいような場合に主に使わ れている.

(2)はホットプレス法などで形成したシリサイド板を ターゲットに使用するが，高純屡ターゲットが入手しに くい場合には，金属上シリコンと別々のターゲットを用 意して，同時にスパッタするコスパッ夕法なども使われ る.

（3）は，ステップカバレージの改良, 選択成長の可能 性から注目され，最近急速に発展している，つぎのよう な反応によるシリサイド膜の形成が報告されている.

$\mathrm{WF}_{6}+\mathrm{SiH}_{4} \rightarrow \mathrm{WSi}_{2}$ (成長温度 $200-300^{\circ} \mathrm{C}$ )

$$
\begin{aligned}
& \mathrm{WF}_{6}+\mathrm{SiH}_{2} \mathrm{Cl}_{2} \rightarrow \mathrm{WSi}_{2}\left(\quad \text { " } 550-650^{\circ} \mathrm{C}\right) \\
& \left.\mathrm{MoCl}_{5}+\mathrm{SiH}_{4} \rightarrow \mathrm{MoSi}_{2} \text { (" " } 600-800^{\circ} \mathrm{C}\right) \\
& \mathrm{TiCl}_{4}+\mathrm{SiH}_{4} \rightarrow \mathrm{TiSi}_{2} \text { (" } 650-700^{\circ} \mathrm{C} \text { ) }
\end{aligned}
$$

特に, CVD WSi ${ }_{2}$ の LSI 製造ラインへの尊入が盛ん で，スループットの良い装鲳が開発されている，最近で は, $\mathrm{SiH}_{2} \mathrm{Cl}_{2}$ を使用する高温 CVD がステップカバレー ジが良いため注目されている，選択成長の可能性も示め されているが, 純タングステンの選択成長ほどには開発 は進んでいない。

\section{4 シリサイドの性算}

LSI 製作工程でウェ八はさまざまな熱好理を受ける. シリサイドに熱処理が加わった時にシリサイドの示す代 表的な現象を幾つか紹介する.

\section{1 組成变化}

金属膜を堆栍したシリコンに熱を加えると，金属とシ リコンの界面で合金反応が起こり, nucleation phase と呼ばれるシリサイドが形成される。この温度は以外に 低く，ある種の金属とシリコンの組み合わせでは，室温 ですでに反応が進んでいる．熱処理を長く続けるか，熱 処理温度を高くすると，合金反応が進行する．最終的に は高融点金属では, ジシリサイド $\left(\mathrm{MSi}_{2}\right)$ が形成される. 熱的に一番安定なためと考えられている. 合金反応はシ リサイド中のシリコンの应散で律速される.

一方, 酸化膜などの上にスパッ夕蒸着, CVD で形成 したシリサイド膜で，金属とシリコンの組成が MSi よ りずれている埸合，これを熱処理すると，余分の金属ま たはシリコンが移動し，最も安定なジシリサイドが形成 される、余分のシリコンまたは金属は，シリサイド表面 などに析出してくる。

\section{2 結晶柆の成長}

一般にスパッ夕などで形成したシリサイド膜は，シリ コン成分が多いとアモルファス状態であるが，金属成分 が多い場合は多結晶化しやすい，高温熱処理が加わる之 多くのシリサイドで, 結晶化がすすみ, 結晶粒径は熱処 理温度および時間の增加によって大きくなる。

例えば，Mo シリサイドや W シリサイドでは，ス パッタで形成した膜の粒径は $10 \mathrm{~nm}$ 以下であるが, 800 ${ }^{\circ} \mathrm{C}$ 以上の熱処理で $100-300 \mathrm{~nm}$ に成長する. また $800^{\circ} \mathrm{C}$ をさかいに, 六方晶系から立方晶系へ結晶跷造が変わる ことも観測されている.

結晶粒径增加にしたがって抵抗率はさがるが、結晶構 造变化にともなう体積膨張（大きなストレスが導入され る), さらには，前述の組成変化とあわせて，熱処理条 件を最適化する必要がある.

\section{3 シリサイド膜の酸化}

シリサイドを酸化䇰囲気中で高温熟処理するとシリサ イドの酸化がおこる. シリサイドがシリコンと直接接し 
ている場合と，シリコン酸化膜あるいは窒化膜上に形成 されている場合とでは酸化のようすが異なる.

酸化膜あるいは窒化膜上のシリサイドを, 酸化䇰囲気 中で熱処理すると，シリコンと金属の両方の酸化が起こ る. 金属とシリコンでは酸化のされやすさに差があり， 金属の酸化物は一般に蒸発しやすい，例元ば Mo シリ サイドでは，シリコンよりモリブデンのほうが酸化され やすい，モリブデン酸化物は融点も $750^{\circ} \mathrm{C}$ と低く蒸発し やすい，このため酸化の初期には，酸化したモリブデン は蒸発し，シリサイドの表面にはシリコン酸化膜が形成 される. シリコン酸化膜がある程度厚くなる上，モリフ デン酸化物の蒸発はシリコン酸化膜で阻害され, 酸化膜 は黒ずんだ色に変化し，シリサイドはしだいにモリブデ ンリッチになる。この現象は非常に複雑で再現性も良く ないし，成長した酸化膜も膜質が要く，実用性にそしい，

一方，シリコン上のシリサイド膜を酸化すると，シリ コン酸化膜が成長する．シリコンの酸化で組成的に不足 になるシリコンは，下のシリコン層より供給される，し たがって，シリサイド層は安定なジシリサイド構造を保 持できる，表面に成長するシリコン酸化膜は，ポリシリ コンを酸化した酸化膜と同程度の膜質をもっている。 こ の性質はシリサイドをLSI の配線に使う上で好都合で ある.

\section{5 シリサイドのデバイスへの応用}

良好な LSI プロセス適合性と, LSI 性能改善の期待 から,シリサイドの LSI 配線への導入研究が，ここ10 年間ほど強力に展開された。

前述したように，シリサイドが示す特有の性質が学術 的にも，非常に興味がある分野で，幾多の優れた研究， 発見があった，現在でも未解決の課題を多数残している が，シリサイドはポリシリコンやシリコン酸化膜などよ 同じように，LSI 要素材料の一つに定着した感がある.

ここではその中から代表的な応用例を紹介する.

\subsection{MOS LSI への応用}

MOS LSI ではゲート扰よび第 1 層配線に使われている ポリシリコンをシリサイドに置き換えて，配線抵抗の低 下を极らう。(1) シリサイド単層構造と。(2) 下層にポ リシリコン，上層にシリサイドを配する 2 層(ポリサイ ド）構造とがある．前者は，プロセスが簡単であるが， 熱処理，熱酸化によってシリサイドの組成が変化するこ 亡を考慮する必要がある．組成変化により．シリサイト の仕事関数が変わるので, MOSトランジスタのしきい 値が変わるなど，場合によっては MOS 特性に影響を与 える. 後者では, MOS 特性はポリシリコンの物性で決 まるので，ポリシリコンゲートプロセスの設計データが 使用できる利点がある．配線抵抗は，ポリシリコン，シ リサイド各層の厚さを選ぶことで，シリサイド単層に近

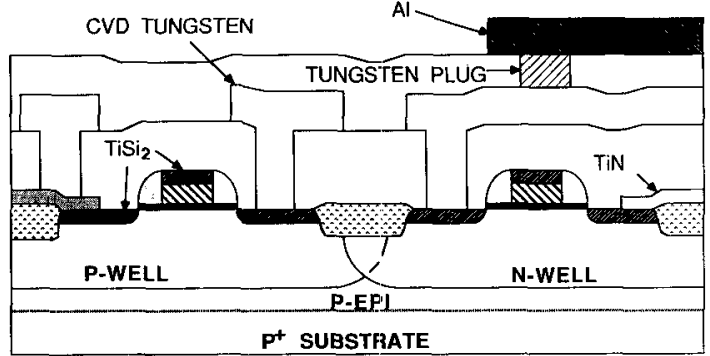

図 1 側壁アシスト電極構造 CMOS の断面 いところまで下げることができる，今日では，ほ上んど の LSI が，モリブテンまたはタングステンのポリサイ ドを採用している.

\section{2 側壁アシスト電極構造}

シリサイドの性質を巧妙に利用して，MOS FET の ソース，ゲート，ドレイン電極を自己整合的に形成する 側壁アシスト電極構造が開発されている。この棈造はバ イポーラ LSIにも適用可能である。ここでは，CMOS に使用した例を示す2゙．図 1 はその断面構造の概略であ る。Tiシリサイドがよく使用される。図では，ソース， ドレインの拡散層は省略した. LSI 製作途中, 側壁酸化 膜を形成した段階で, ゲート電極のポリシリコン, ソー ス，ドレイン領域のシリコンが露出する．この表面に Ti 膜を形成して熱処理すると. シリコンと接している $\mathrm{Ti}$ はシリコンと反応して, $\mathrm{TiSi}_{2}$ を形成する. Ti は溶 解するが、 $\mathrm{TiSi}_{2}$ は腐食しないエッチング液を使用し て、未反応の Ti 老除去する. ゲート電極, ソース, ド レイン層がシリサイド膜で赛打ちされ低抵抗化がはかれ ると同時に, ゲート電極よソース, ドレイン電極の距離 を，ゲート電極側壁の酸化膜厚で自己整合的に決定でき る。こ机は，10 nmオーダで制御可能であり，サブミ クロン LSI 技術として，今後さらに発展するであろう． なお図には, LSI の将来像として考えられているタング ステン選択成長を用いた多層配線も同時に示している.

\section{6 ま とめ}

ポリシリコン配線をシリサイドで裹打ちするポリシリ コン構造が広範同に採用されるようになり，金属ケイ化 物（シリサイド）はLSI 配線材料として重要な位置を 占めるようになった．シリサイドの採用により，配線抵 抗が下がり，LSI の性能が大幅に改良された。しかし一 方では，さらに低抵抗率化が求められており，複合構造 配線など，今後大いに知恵をしぼる必要がある。

\section{文献}

1）全体に，伊藤隆司，石川 元，中村宏昭，“VLSI の薄 膜技術”，丸普, 1986, pp.171-192.

2) R.A. Chapman, IEDM Digest of Tech. Papers, 362 (1987) 